\title{
ANALISIS CURAH HUJAN DAN DEBIT MODEL SWAT DENGAN METODE MOVING AVERAGE DI DAS CILIWUNG HULU
}

\author{
Analysis of Rainfall and Discharge with SWAT Model Using the Moving Average Method in \\ Ciliwung Hulu Watershed
}

\author{
Defri Satiya Zumaa ${ }^{\mathrm{a}}$ Kukuh Murtilaksono ${ }^{\mathrm{b}}$, Yuli Suharnoto ${ }^{\mathrm{c}}$ \\ a Program Studi Ilmu Pengelolaan Daerah Aliran Sungai, Sekolah PascasarjanaInstitut Pertanian Bogor, Kampus \\ IPB Dramaga, Bogor 16680 _foresternoxy@gmail.com \\ ${ }^{b}$ Departemen Ilmu Tanah dan Sumberdaya Lahan, Fakultas Pertanian, Institut Pertanian Bogor, Kampus IPB \\ Darmaga, Bogor 16680. \\ 'Departemen Teknik Sipil dan Lingkungan, Fakultas Teknik Pertanian, Institut Pertanian Bogor, Kampus IPB \\ Darmaga, Bogor 16680.
}

\begin{abstract}
Watershed can be regarded as a hydrological system that has a function in transforming rainwater as an input into outputs such as flow and sediment. The transformation of inputs into outputs has specific forms and properties. The transformation involves many processes, including processes occurred on the surface of the land, river basins, in soil and aquifer. This study aimed to apply the SWAT model in Ciliwung Hulu Watershed, asses the effect of average rainfall on 3 days, 5 days, 7 days and 10 days of the hydrological characteristics in Ciliwung Hulu Watershed. The correlation coefficient $(r)$ between rainfall and discharge was positive, it indicated that there was an unidirectional relationship between rainfall and discharge in the upstream, midstream and downstream of the watershed. The upper limit ratio of discharge had a downward trend from upstream to downstream, while the lower limit ratio of discharge had an upward trend from upstream to downstream. It showed that the discharge peak in Ciliwung Hulu Watershed from upstream to downstream had a downward trend while the baseflow from upstream to downstream had an upward trend. It showed that the upstream of Ciliwung Hulu Watershed had the highest ratio of discharge peak and baseflow so it needs the soil and water conservations and technical civil measures. The discussion concluded that the SWAT model could be well applied in Ciliwung Hulu Watershed, the most affecting average rainfall on the hydrological characteristics was the average rainfall of 10 days. On average rainfall of 10 days, all components had contributed maximally for river discharge.
\end{abstract}

Keywords: Rainfall, Discharge, Moving Average, SWAT model

(Diterima: 26-09-2016; Disetujui: 04-04-2017)

\section{Pendahuluan}

Daerah Aliran Sungai (DAS) merupakan suatu daerah yang dibatasi oleh topografi secara alami dimana air hujan yang jatuh di atasnya akan mengalir keluar melalui suatu outlet yang sama. DAS dapat dipandang sebagai sebuah sistem hidrologi, dalam artian berfungsi mengalihragamkan masukan (input) yang berupa air hujan menjadi keluaran (output) seperti aliran dan sedimen. Proses pengalih ragaman masukan menjadi keluaran memiliki bentuk dan sifat tertentu. Peristiwa ini melibatkan banyak proses, meliputi proses yang terjadi pada permukaan lahan, alur sungai, lapisan tanah dan aquifer. Aliran yang tercatat pada outlet DAS biasanya disajikan dalam bentuk hidrograf. Hidrograf adalah grafik yang menunjukan fenomena aliran (tinggi muka air dan debit) yang dihubungkan dengan waktu.

Curah hujan merupakan salah satu unsur iklim yang penting di Indonesia karena keragamannnya sangat tinggi baik menurut waktu maupun menurut tempat. Interaksi antara faktor pengendali iklim di Indonesia seperti posisi silang antara 2 benua dan 2 samudera dan faktor yang mempengaruhi iklim di Indonesia seperti posisi di ekuator, membuat Indonesia memiliki banyaknya pola curah hujan dan ketidakpastian yang tinggi dalam prediksi (BPPP, 2013). Curah hujan merupakan faktor utama pengendali siklus hidrologi suatu DAS (Asdak, 2007). Pola dan sebaran curah hujan merupakan hal penting dalam manajemen sumber daya air suatu wilayah (Mukid dan Wilandari, 2012). Selain itu informasi mengenai pola sebaran curah hujan sangat membantu dalam kegiatan pertanian (Riajaya, 2006; Sudiharto, 2004).

Dalam penelitian ini curah hujan dan debit yang digunakan adalah curah hujan dan debit model SWAT dari empat stasiun hujan yaitu stasiun Katulampa, stasiun Gadog, stasiun Gunung mas dan stasiun Citeko.

Soil and Water Assessment Tool (SWAT) adalah model hidrologi yang dikembangkan untuk memprediksi pengaruh pengelolaan lahan terhadap hasil air, sedimen, muatan pestisida, dan kimia hasil pertanian. Model SWAT dikembangkan oleh United State Departement of Agricultural-Agricultural Research Services (USDA-ARS). Model SWAT adalah model hidrologi yang banyak digunakan untuk mengevaluasi dampak perubahan iklim, penggunaan lahan, dan pengelolaan 
lahan terhadap karakteristik hidrologi (Arnold et al., 2010)

Tujuan penelitian ini adalah (1) Menjalankan model SWAT di DAS Ciliwung Hulu. (2) Mengkaji curah hujan rata-rata berapa harian yang berpengaruh terhadap karakteristik hidrologi di DAS Ciliwung Hulu dengan menggunakan metode Moving Average.

\section{Metodologi}

\subsection{Lokasi Penelitian}

Penelitian ini dilakukan di DAS Ciliwung Hulu seluas 15082 ha dan secara geografis terletak pada $106^{\circ}$ $49^{\circ} 40^{\prime \prime}-107^{\circ} 00^{\prime} 15^{\prime \prime}$ BT dan 6 $6^{\circ} 38^{\prime} 15^{\prime \prime}-6^{\circ} 46^{\prime} 05^{\prime \prime}$ LS. Secara administratif DAS Ciliwung Hulu mencakup 30 desa di Kabupaten Bogor yaitu 2 desa (Kecamatan Sukaraja), 7 desa (Kecamatan Ciawi), 10 desa (Kecamatan Cisarua), 11 desa (Kecamatan Megamendung) dan 1 desa di Kecamatan Kota Bogor Timur. Penelitian dilakukan mulai bulan Oktober 2015 sampai dengan bulan Maret 2016. Peta daerah penelitian disajikan pada Gambar 1.

\subsection{Alat dan bahan}

Peralatan yang digunakan dalam penelitian ini adalah (1). Seperangkat komputer dengan perangkat lunak
ArcGIS 10.1, ArcSWAT 2012 dan Microsoft Office 2010 (2) GPS.

Bahan yang digunakan dalam penelitian ini berupa data spasial meliputi (1). Peta tutupan lahan (2). Peta Jenis Tanah dan (3) Digital Elevation Model (DEM) dari citra SRTM (30 x 30). Data di atas digunakan untuk membentuk jaringan sungai, titik outlet, batas DAS dan HRU. Selain itu dilakukan pengumpulan data iklim dan data debit aktual di SPAS. Data iklim berupa data curah hujan harian, suhu harian, kecepatan angin, radiasi matahari dari setiap stasiun pengamatan yang terdapat di sekitar DAS Ciliwung hulu tahun periode tahun 2004-2013.

\subsection{Pengumpulan Data}

Data yang digunakan mencakup data Digital Elevation Model (DEM) dengan resolusi $30 \mathrm{~m}$ x $30 \mathrm{~m}$ yang bersumber dari SRTM (Shuttle Radar Thopography Mission), peta tutupan lahan tahun 2014 dengan skala 1:250.000, peta jenis tanah dalam bentuk shapefile dengan skala 1: 50.000. Data lainnya adalah data iklim di DAS Ciliwung Hulu. Data iklim meliputi data curah hujan, suhu udara, kelembaban udara, radiasi matahari, dan kecepatan angin dari tahun 2010 sampai 2015. Data yang digunakan dalam penelitian ini diperoleh dari Balai Pengelolaan Daerah Aliran Sungai dan Hutan Lindung (BPDASHL) Citarum Ciliwung. Diagram alir tahapan penelitian disajikan pada Gambar 2.

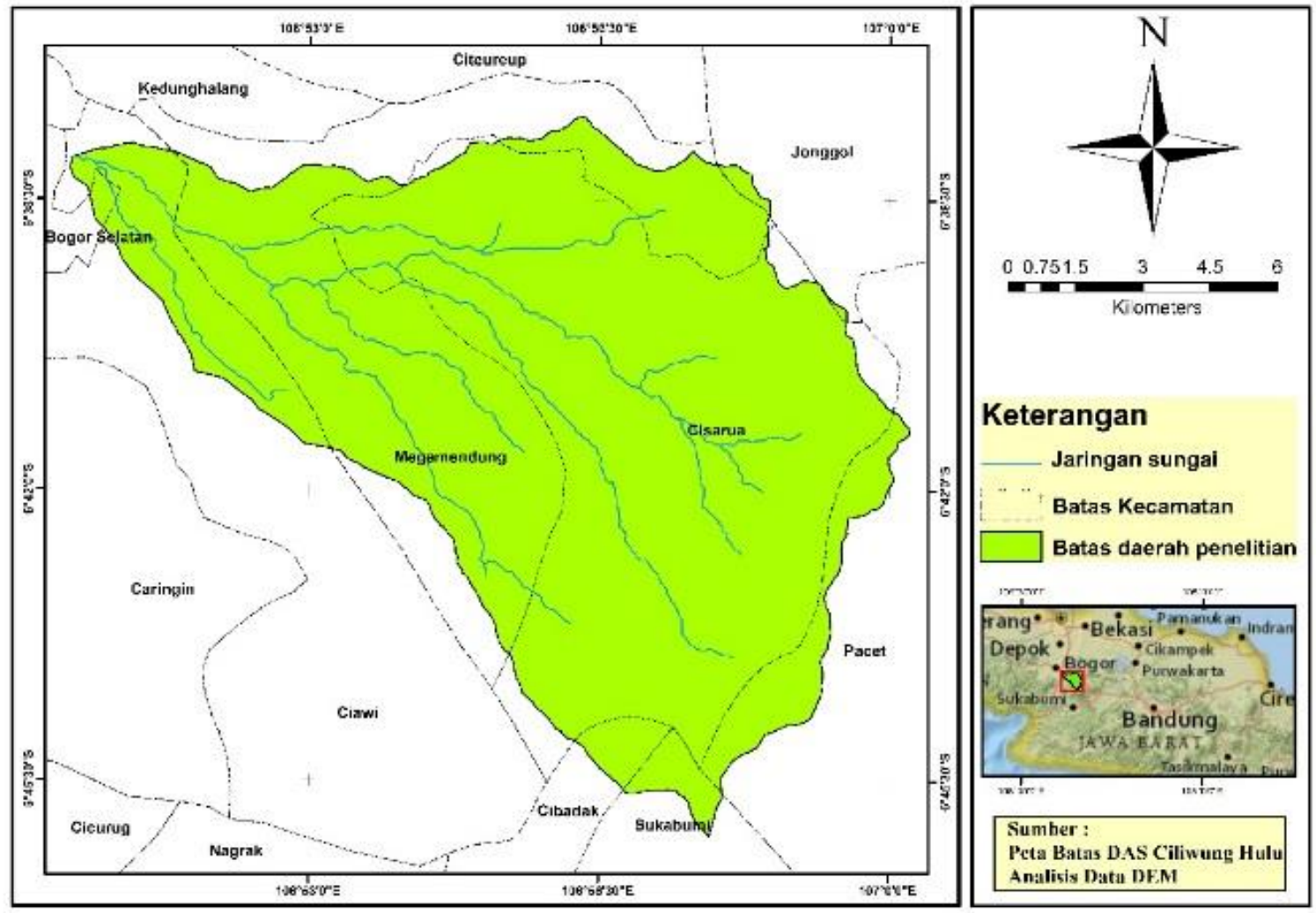

Gambar 1. Lokasi Penelitian 


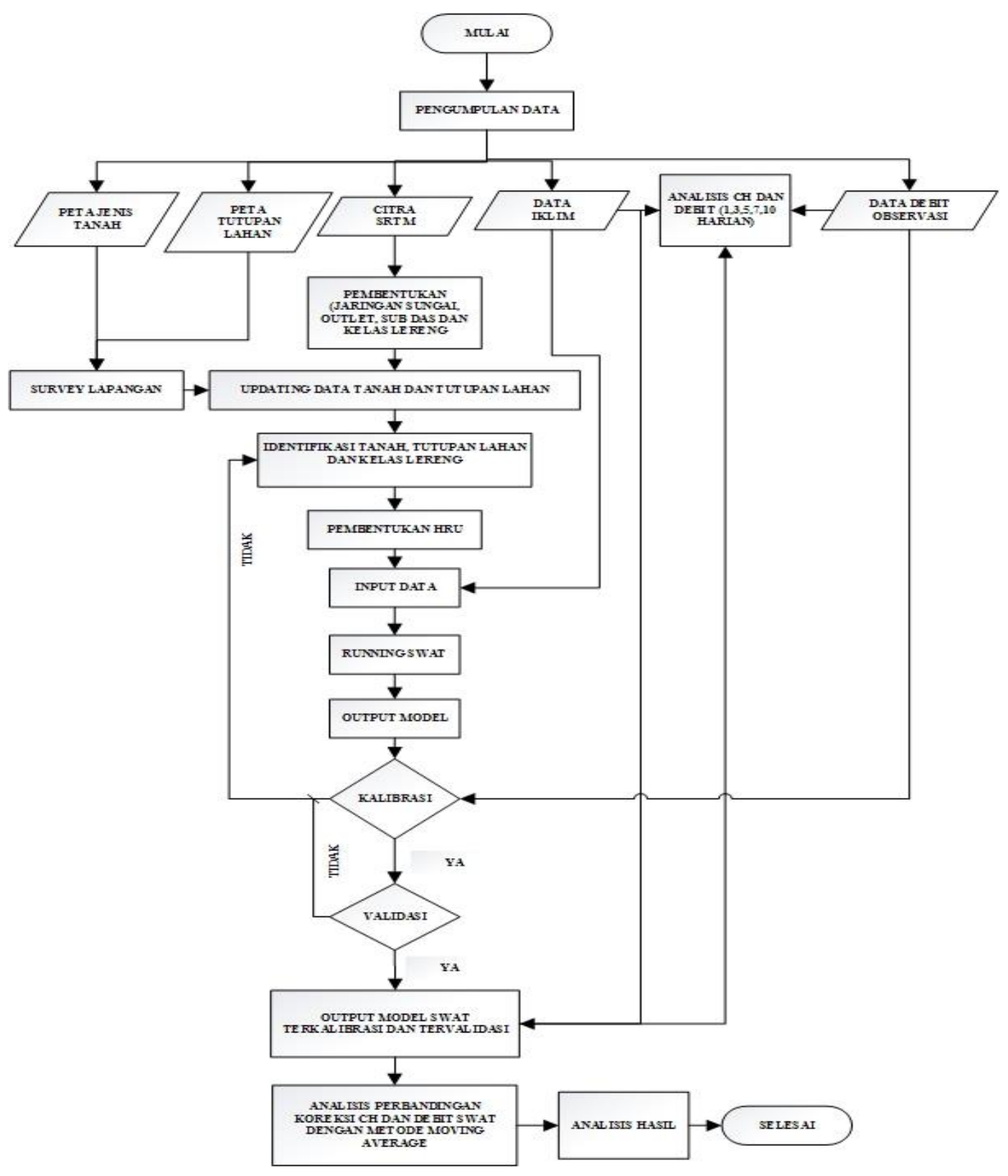

Gambar 2. Diagram alir tahapan penelitian

\subsection{Metode Analisis Data}

a. Input Data SWAT

- Delineasi DAS (Watersheed Deliniator) dengan data input berupa data DEM.

- $\quad$ Analisis HRU (Hydrology Respont Unit Analysis) dengan data input peta penggunaan lahan, peta topografi, dan peta serta data sifat fisik tanah.

- Basis data iklim (Weather Generator Data) dengan membuat data generator iklim (weather generator data) hasil perhitungan data curah hujan, suhu, radiasi matahari, kelembaban, dan kecepatan angin.

\section{b. Menjalankan Model SWAT}

- Delineasi DAS (Watersheed Deliniator) dengan tahapan kegiatan: input data DEM (add DEM grid), penentuan jaringan sungai (stream definition), penentuan outlet (outlet and inlet definition), seleksi dan penentuan outlet DAS (watershed outlet selection and definition), dan perhitungan parameter sub DAS (calculate subbasin parameter).

- Analisis HRU (Hydrology Respont Unit Analysis) dengan mendefinisikan data masukan melalui overlay peta penggunaan lahan, peta tanah, dan kelas lereng (Landuse/Soil/Slope definition).

- Basis data iklim (Weather Generator Data) model SWAT dioperasikan melalui sub menu weather data definition. Pada tahap ini dilakukan masukan data iklim (Weather Generator Data), curah hujan, temperatur, kelembaban, radiasi matahari, dan kecepatan angin. 
- Membangun data masukan model SWAT berdasarkan masukan pada tahap 1 hingga 3 terbentuk secara otomatis dengan memilih sub menu Write All.

- Simulasi SWAT (SWAT Simulation) dilakukan dengan memilih waktu yang akan disimulasikan pada mode Run SWAT. Penyimpan data output hasil simulasi dilakukan dengan memilih Read SWAT Output.

\section{c. Perhitungan Prediksi Debit Aliran pada Model SWAT}

SWAT menggunakan metode SCS-CN (Soil Conservation Service-Curve Number) dalam menduga limpasan permukaan $\left(\mathrm{Q}_{\text {surf }}\right)$. Metode ini dikembangkan untuk menghitung runoff tutupan lahan dan jenis tanah yang bervariasi. Persamaan SCS-CN disajikan pada persamaan (2) dan (3) (Neitsch et al., 2004).

$Q \operatorname{surf}=\frac{(\text { R day }-0,2 S)^{2}}{(\text { Rday }+0,8 S)}$

$s=25,4\left(\frac{1000}{C N}-10\right)$

Keterangan:

$\mathrm{R}_{\text {day }} \quad$ : curah hujan per hari ( $\left.\mathrm{mm}\right)$

$\mathrm{Q}_{\text {surf }}$ : limpasan permukaan $(\mathrm{mm})$

$\mathrm{S}$ : parameter retensi $(\mathrm{mm})$

CN : SCS Curve Number

Limpasan permukaan maksimum dihitung dengan memodifikasi metode rasional dengan persamaan (4) (Neitsch et al., 2004).

$q_{\text {peak }}=\frac{\text { C.i. Area }}{3.6}$

Keterangan:

$\mathrm{q}_{\text {peak }}$ : laju limpasan permukaan maksimum $\left(\mathrm{m}^{3} / \mathrm{s}\right)$

Area : luas wilayah DAS $\left(\mathrm{km}^{2}\right)$

C : koefisien limpasan permukaan

I : intensitas curah hujan ( $\mathrm{mm} / \mathrm{jam})$

Waktu konsentrasi $\left(t_{\text {conc }}\right)$ adalah jumlah waktu aliran $\left(\mathrm{t}_{\mathrm{ov}}\right)$ dan waktu aliran di sungai $\left(\mathrm{t}_{\mathrm{ch}}\right)$ (Neitsch et al., 2004).

$t_{c h}=\frac{L_{s l p . n^{0,6}}^{0,6}}{18 \cdot s l p^{0,8}}$ dan $t_{c h}=\frac{o, 62 \cdot L \cdot n^{0,75}}{\text { Area }^{0,125} \cdot s l p_{c h}^{0,375}}$

Keterangan:

$\mathrm{t}_{\mathrm{ov}} \quad$ : waktu konsentrasi umtuk aliran di lahan (jam)

$\mathrm{t}_{\mathrm{ch}}$ : waktu konsentrasi untuk aliran di sungai (jam)

$\mathrm{L}_{\text {slp }}$ : panjang lereng DAS (m)

$\mathrm{L} \quad$ : rata- rata panjang aliran sungai di DAS $(\mathrm{km})$

Slp : rata-rata lereng di lahan $\left(\mathrm{m} \mathrm{m}^{-1}\right)$

Slp ch : rata rata lereng di sungai $\left(\mathrm{m} \mathrm{m}^{-1}\right)$

$\mathrm{N}$ : koefisien kekasaran Manning

Model SWAT menghitung perkolasi disetiap lapisan tanah. Perkolasi terjadi jika kandungan air tanah (SWly) pada lapisan tersebut melebihi kapasitas lapangnya (Fcly). Kelebihan air pada lapisan tanah dihitung dengan persamaan (6)

$S W_{i y, e x c e s s}=S W l y-F C l y$ jika SWly $>$ FCly

$S W_{\text {iy,excess }}=0 \quad$ jika SWly $<$ FCly

Keterangan :

$\mathrm{Sw}_{\text {ly }}$ : kandungan air tanah $(\mathrm{mm})$

$\mathrm{Fc}_{\mathrm{ly}}$ : kapasitas lapang $(\mathrm{mm})$

Aliran bawah tanah atau base flow $\left(\mathrm{Q}_{\mathrm{gw}}\right)$ dihitung pada persamaaan $(7)$

$Q g w=\frac{8000 . K s a t}{L^{2} g w} x h_{w t b l}$

Keterangan :

$\mathrm{K}_{\text {sat }}$ : konduktivitas hidrolika jenuh (saturated hydraulic conductivity) ( $\mathrm{mm} / \mathrm{hari})$

$\mathrm{L}_{\mathrm{gw}}^{2}$ : jarak sub DAS dari sistem air tanah ke saluran utama $(\mathrm{m})$

$\mathrm{h}_{\mathrm{wtbl}}:$ tinggi muka air tanah (m).

\section{d. Kalibrasi dan Validasi}

Proses kalibrasi merupakan penyesuaian kombinasi nilai parameter-parameter yang berpengaruh terhadap kondisi hidrologi DAS, sehingga diperoleh hasil model yang mendekati hasil pengukuran. Kalibrasi model dilakukan secara manual dengan memasukan nilai setiap parameter secara coba-coba.

Metode statistik yang digunakan untuk tujuan kalibrasi model adalah efisiensi model Nash-Sutcliffe (NS) yang direkomendasiikan oleh The American Society of Civil Engineers. Adapun persamaannya yaitu sebagai berikut (persamaan (8)):

$$
N S E=\frac{\sum_{i=1}^{n}\left(Y_{i}^{o b s}-Y_{i}^{\text {sim }}\right)^{2}}{\sum_{i=1}^{n}\left(Y_{i}^{\text {obs }}-Y_{i}^{\text {mean }}\right)^{2}} .
$$

Keterangan:

$\mathrm{Y}_{\mathrm{i}}{ }^{\mathrm{obs}}=$ data observasi/ pengukuran

$\mathrm{Y}_{\mathrm{i}}{ }^{\mathrm{sim}}=$ data simulasi

$\mathrm{Y}^{\text {mean }}=$ rata-rata data observasi/pengukuran

Efisiensi model Nash-Sutcliffe terdiri atas 3 kelas yaitu:

1. Baik, jika $\mathrm{NS} \geq 0.75$

2. Memuaskan, jika $0,75>\mathrm{NS}>0.36$

3. Kurang memuaskan, jika NS < 0.36 (Nash 1970).

\section{e. Analisa Karakteristik Hujan dan Debit Harian Rata-Rata 3 Harian, 5 Harian, 7 Harian, dan 10 Harian dengan Metode Moving Average}

Analisis karakteristik hujan dan debit harian rata-rata 3, 5, 7, dan 10 harian dengan cara membandingkan debit hasil kalibrasi model SWAT tanpa bioretensi dan curah hujan rata-rata $3,5,7$, dan 10 harian pada bagian hulu, tengah dan hilir. Perhitungan debit dan curah hujan rata-rata sebagai berikut:

- Curah hujan rata-rata 3 harian $\left(\mathrm{R}_{3}\right)$

$\mathrm{R}_{3}=\left(\mathrm{R}_{(\mathrm{n}-1)}+\mathrm{R}_{\mathrm{n}}+\mathrm{R}_{(\mathrm{n}+1)}\right) / 3$

dimana $\mathrm{R}$ : curah hujan harian $\mathrm{n}$ : hari ke-n 
- Debit rata-rata 3 harian $\left(\mathrm{Q}_{3}\right)$

$\mathrm{Q}_{3}=\left(\mathrm{Q}_{(\mathrm{n}-1)}+\mathrm{Q}_{\mathrm{n}}+\mathrm{Q}_{(\mathrm{n}+1)}\right) / 3$

dimana Q: debit harian $\mathrm{n}$ : hari ke-n

- Curah hujan rata-rata 5 harian $\left(\mathrm{R}_{5}\right)$

$\mathrm{R}_{5}=\left(\mathrm{R}_{(\mathrm{n}-1)}+\mathrm{R}_{(\mathrm{n}-2)}+\mathrm{R}_{\mathrm{n}}+\mathrm{R}_{(\mathrm{n}+1)}+\mathrm{R}_{(\mathrm{n}+2)}\right) / 5$

dimana R: curah hujan harian $\mathrm{n}$ : hari ke-n

- Debit rata-rata 5 harian $\left(\mathrm{Q}_{5}\right)$

$\mathrm{Q}_{5}=\left(\mathrm{Q}_{(\mathrm{n}-1)}+\mathrm{Q}_{(\mathrm{n}-2)}+\mathrm{Q}_{\mathrm{n}}+\mathrm{Q}_{(\mathrm{n}+1)}+\mathrm{Q}_{(\mathrm{n}+2)}\right) / 5$

dimana $\mathrm{Q}$ : debit harian $\mathrm{n}$ : hari ke-n

- Curah hujan rata-rata 7 harian $\left(\mathrm{R}_{7}\right)$

$\mathrm{R}_{7}=\left(\mathrm{R}_{(\mathrm{n}-1)}+\mathrm{R}_{(\mathrm{n}-2)}+\mathrm{R}_{(\mathrm{n}-3}+\mathrm{R}_{\mathrm{n}}+\mathrm{R}_{(\mathrm{n}+1)}+\mathrm{R}_{(\mathrm{n}+2)}\right.$

$\left.+\mathrm{R}_{(\mathrm{n}+3)}\right) / 7$

dimana R: curah hujan harian $\mathrm{n}$ : hari ke-n

- Debit rata-rata 7 harian $\left(\mathrm{Q}_{7}\right)$

$\mathrm{Q}_{7}=\left(\mathrm{Q}_{(\mathrm{n}-1)}+\mathrm{Q}_{(\mathrm{n}-2)}+\mathrm{Q}_{(\mathrm{n}-3)}+\mathrm{R}_{\mathrm{n}}+\mathrm{Q}_{(\mathrm{n}+1)}+\mathrm{Q}_{(\mathrm{n}+2)}\right.$

$\left.+\mathrm{Q}_{(\mathrm{n}+3)}\right) / 7$

dimana Q: debit harian n: hari ke-n

- Curah hujan rata-rata 10 harian $\left(\mathrm{R}_{10}\right)$

$\mathrm{R}_{10}=\left(\mathrm{R}_{(\mathrm{n}-1)}+\mathrm{R}_{(\mathrm{n}-2)}+\mathrm{R}_{(\mathrm{n}-3)}+\mathrm{R}_{(\mathrm{n}-4)}+\mathrm{R}_{(\mathrm{n}-5)}+\mathrm{R}_{(\mathrm{n}+1)}\right.$

$\left.+\mathrm{R}_{(\mathrm{n}+2)}+\mathrm{R}_{(\mathrm{n}+3)}+\mathrm{R}_{(\mathrm{n}+4)}+\mathrm{R}_{(\mathrm{n}+5)}\right) / 10$

dimana $\mathrm{R}$ : curah hujan harian $\mathrm{n}$ : hari ke-n

- Debit rata-rata 10 harian $\left(\mathrm{Q}_{10}\right)$

$\mathrm{Q}_{10}=\left(\mathrm{Q}_{(\mathrm{n}-1)}+\mathrm{Q}_{(\mathrm{n}-2)}+\mathrm{Q}_{(\mathrm{n}-3)}+\mathrm{Q}_{(\mathrm{n}-4)}+\mathrm{Q}_{(\mathrm{n}-5)}+\mathrm{Q}_{(\mathrm{n}+1)}\right.$

$\left.+\mathrm{Q}_{(\mathrm{n}+2)}+\mathrm{Q}_{(\mathrm{n}+3)}+\mathrm{Q}_{(\mathrm{n}+4)}+\mathrm{Q}_{(\mathrm{n}+5)}\right) / 10$

dimana Q: debit harian $\mathrm{n}$ : hari ke-n

\section{f. Analisis Perbandingan Curah Hujan dan Debit SWAT dengan Metode Moving Average}

Setelah diperoleh data debit dan curah hujan harian dengan metode Moving Average, selanjutnya dilakukan analisis statistik untuk mengetahui hubungan antara curah hujan dan debit. Analisis curah hujan dan debit dengan metode Moving Average digunakan untuk mengetahui curah hujan berapa harian yang berpengaruh di hulu, tengah dan hilir di DAS Ciliwung Hulu. Hubungan antara curah hujan dan debit yang dapat diketahui dari besarnya nilai r (korelasi) dari masing-masing analisis karakteristik curah hujan. Semakin besar nilai r (korelasi) maka semakin erat hubungan antara curah hujan dan debit.

\section{g. Analisis Ratio Debit rata-rata (harian, 3 harian, 5 harian, 7 harian dan 10 harian) model SWAT}

Analisis debit ratio model SWAT menggunakan metode statistik yaitu ditentukan dahulu nilai dari batas bawah (5\%), nilai tengah (median) dan batas atas (95\%). Setelah diperoleh nilai tersebut selanjutnya dicari ratio antara batas atas (95\%) dan nilai tengah (median), batas bawah (5\%) dan nilai tengah (median). Dari hasil perhitungan tersebut diperoleh ratio debit puncak dan ratio debit bawah. Perhitungan ini dilakukan pada debit ratarata (harian, 3 harian, 5 harian, 7 harian dan 10 harian) di daerah hulu tengah dan hilir, kemudian disusun trend grafik dari hulu ke hilir.

\section{Hasil dan Pembahasan}

\subsection{Deliniasi Sub DAS}

Deliniasi DAS pada model ArcSWAT dilakukan secara otomatis. Data input Digital Elevation Model skala 30 x 30 meter yang berisi informasi topografi sub DAS Ciliwung hulu diolah dalam ArcSWAT menggunakan Watershed Deliniator. Hasil deliniasi model ArcSWAT dengan DEM-base 345 ha terbentuk 21 sub DAS. Luas sub DAS yang terbentuk antara 37,57 ha sampai $2.246,20$ ha. Titik outlet berada pada sub DAS nomor 1 yang terletak di bagian hilir (Katulampa). Peta pembagian sub DAS tersaji pada Gambar 2.

\subsection{Kalibrasi dan Validasi}

Kalibrasi dilakukan untuk mengetahui hubungan antara total air sungai hasil model SWAT dengan total air sungai hasil pengukuran. Data total air sungai yang digunakan untuk proses kalibrasi adalah data tahun 2013 di SPAS Katulampa. Proses validasi menggunakan tahun 2014. Kalibrasi dilakukan secara manual dengan memasukan nilai setiap parameter secara manual (trial and error).

Proses kalibrasi dilakukan dengan merubah parameter yang berpengaruh terhadap perubahan total air sungai hasil model SWAT. Beberapa parameter yang dirubah dalam proses kalibrasi adalah CH_K2 (konduktivitas hidrolik sungai), CH_N2 (koefisien Manning untuk saluran utama), ALPHA_BNK (faktor alpha aliran dasar untuk bank storage), GW_DELAY (masa jeda air di dalam tanah untuk kembali ke sungai), ALPHA_BF (faktor alpha aliran dasar), GWQMIN (ketinggian minimum aliran dasar), SHALLST (kedalaman awal air di aquifer dangkal), DEEPST (kedalaman awal air di aquifer dalam), REVAPMN (kedalaman ambang batas air di aquifer dangkal untuk terjadinya revap), EPCO (faktor uptake tanaman), ESCO (faktor evaporasi tanah). Parameter sensitif yang digunakan tersaji pada Tabel 1.

Parameter CN2, ESCO dan EPCO berpengaruh terhadap jumlah aliran permukaan. Parameter CN2 dapat memprediksi jumlah aliran permukaan atau infiltrasi akibat curah hujan. Parameter ESCO menentukan jumlah air dalam tanah yang akan mempengaruhi bilangan kurva aliran permukaan dan proses infiltrasi yang terjadi. Parameter EPCO berpengaruh terhadap aliran permukaan karena kemampuan akar tanaman yang dapat menyerap air dan mempunyai pengaruh terhadap transpirasi sehingga dengan demikian memiliki dampak terhadap kelembaban tanah. Parameter ALPHA_BANK, GW_DELAY, GW_REVAP, GWQMN, dan RCHRG_DP berpengaruh terhadap aliran air bawah tanah. Parameter CH_N2, CH_K2, ALPHA_BANK, dan SURLAG berpengaruh terhadap bentuk hidrograf.

Parameter ALPHA_BF merupakan indeks respons lahan terhadap aliran bawah tanah sehingga terisi kembali. Nilai 0.1-0.3 menunjukkan lahan dengan respons 
yang lambat terhadap perubahan aliran, nilai $0.9-1$ menunjukan lahan dengan respon cepat terhadap perubahan aliran bawah tanah. Nilai parameter ALPHA_BF yang dimasukan pada proses kalibrasi sebesar 0.9 yang menunjukkan lahan DAS Ciliwung hulu mempunyai respons cepat terhadap perubahan aliran air bawah tanah. Nilai tersebut diperoleh melalui perhitungan berdasarkan data total air sungai hasil pengukuran sehingga menghasilkan total air sungai model yang mendekati total air sungai hasil pengukuran.

Parameter GW_DELAY merupakan parameter waktu antara air mengalir dari profil tanah menuju zona jenuh. Nilai parameter GW_DELAY pada proses kalibrasi sebesar 30. Parameter GWQMN merupakan ambang batas kedalaman air di akuifer dangkal untuk memungkinkan terjadinya aliran air. Aliran air bawah tanah ke sungai dapat terjadi apabila kedalaman air di akuifer dangkal sama atau lebih besar dari nilai GWQMN. Metode trial and error dilakukan untuk memperoleh nilai parameter GWQMN yang menghasilkan total air sungai model yang mendekati total air sungai hasil pengukuran. Nilai yang di pilih pada proses kalibrasi sebesar 5500.

Parameter ESCO merupakan koefisien kebutuhan air yang diambil dari lapisan tanah paling bawah untuk memenuhi kebutuhan evaporasi tanah sebagai efek dari adanya kapilaritas dan rekahan. Nilai parameter ESCO pada proses kalibrasi sebesar 0,85 melalui proses trial and error.
Parameter EPCO merupakan parameter yang memperhitungkan jumlah air setiap hari merupakan fungsi dari jumlah air yang dibutuhkan tanaman untuk transpirasi dan jumlah air yang tersedia di dalam tanah. Jika lapisan teratas tanah tidak mempunyai kandungan air yang cukup untuk memenuhi potensial penggunaan air maka lapisan tanah di bawahnya dapat mengganti peran lapisan teratas tanah. Nilai parameter EPCO sebesar 0,15 melalui trial and error. Metode Hargreaves digunakan untuk perhitungan Evapotranspirasi potensial. Hal ini dikarenakan dengan menggunakan metode Hargreaves lebih mempresentasikan nilai evapotranspirasi di DAS Ciliwung hulu yaitu berkisar \pm 1000 $\mathrm{mm} /$ tahun.

Parameter CH_N2 merupakan nilai koefisien manning's saluran utama. Nilai pada tabel Manning's dimasukan sebagai nilai parameter $\mathrm{CH}_{\mathbf{N}} \mathrm{N} 2$ melalui trial and error dengan menyesuaikan dengan kondisi saluran utama di lapang. Saluran sungai DAS Ciliwung hulu yang masih alami didominasi oleh saluran yang masih banyak pohon dan berbatu. Berdasarkan nilai pada tabel Manning's, maka diperoleh nilai sebesar 0.05 .

Nilai Parameter CH_K2 merupakan nilai efektif konduktivitas hidrolik pada saluran alluvium. Nilai Parameter CH_K2 pada proses kalibrasi sebesar 128 . Nilai tersebut menggambarkan bahwa kecepatan kehilangan air pada saluran sangat tinggi. Hal tersebut disebabkan oleh karakteritik material dasar saluran yang merupakan kerikil dan pasir kasar.

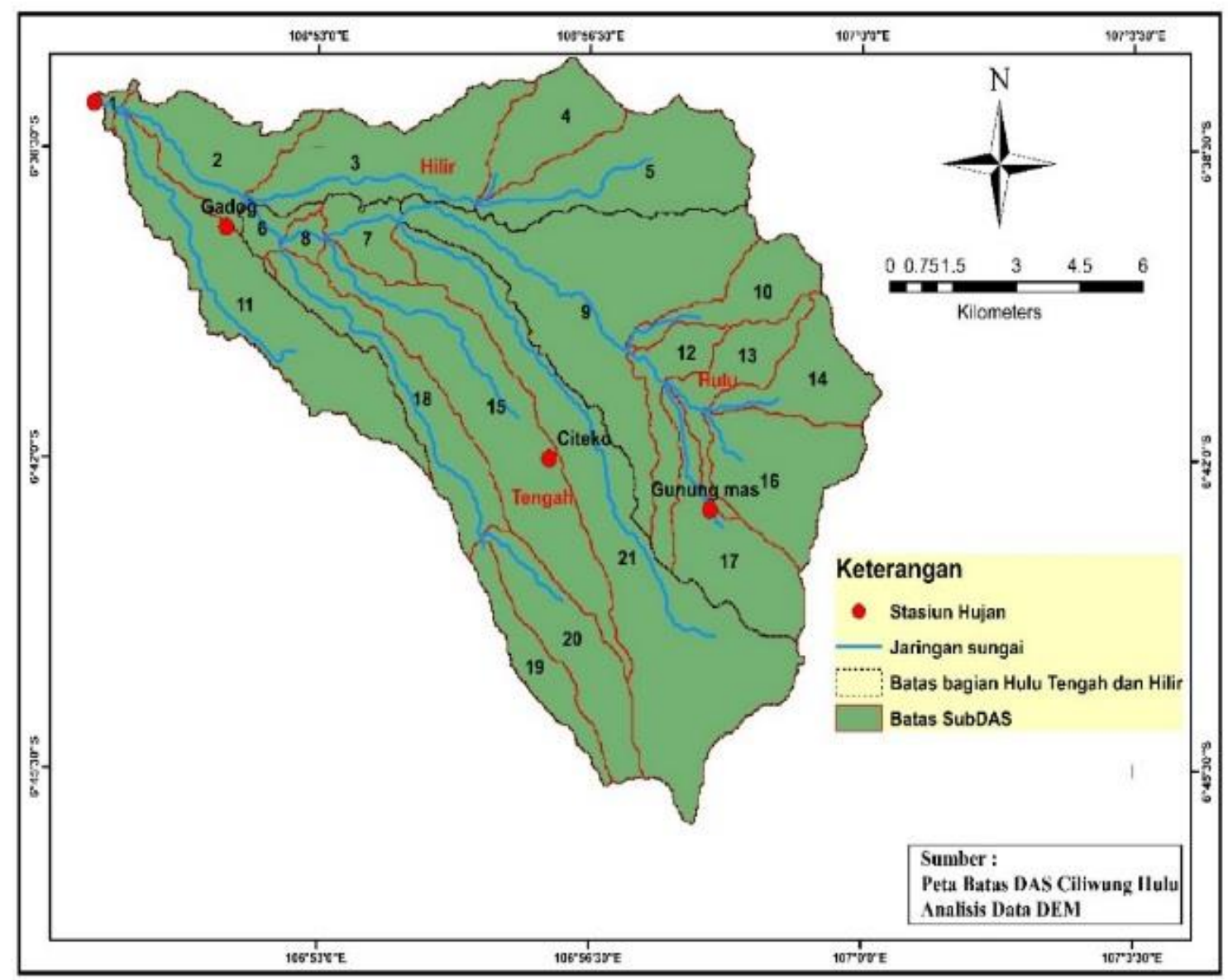

Gambar 3. Peta batas sub-DAS Ciliwung Hulu 
JPSL Vol. 7 (2): 98-106, Agustus 2017

Tabel 1. Data parameter sensitif model SWAT

\begin{tabular}{|c|c|c|c|c|}
\hline \multirow{2}{*}{ No } & \multirow{2}{*}{ Parameter } & \multicolumn{2}{|c|}{ Selang } & \multirow{2}{*}{$\begin{array}{c}\text { Nilai } \\
\text { Terpilih }\end{array}$} \\
\hline & & Min & $\operatorname{Max}$ & \\
\hline 1 & CH_K2 & $-0,01$ & 500 & 128 \\
\hline 2 & CH_N2 & $-0,01$ & 0,3 & 0,05 \\
\hline 3 & ALPHA_BNK & 0 & 1 & 0,13 \\
\hline 4 & GW_DELAY & 0 & 500 & 30 \\
\hline 5 & ALPHA_BF & 0 & 1 & 0,9 \\
\hline 6 & GWQMIN & 0 & 7.500 & 5.500 \\
\hline 7 & SHALLST & 0 & 7.500 & 5.000 \\
\hline 8 & DEEPST & 0 & 10.000 & 7.500 \\
\hline 9 & REVAPMN & 0 & 1.000 & 0,02 \\
\hline 10 & ESCO & 0 & 1 & 0,85 \\
\hline 11 & ЕРCO & 0 & 1 & 0,2 \\
\hline
\end{tabular}

Hasil pengujian model debit awal sebelum kalibrasi dibandingkan dengan debit hasil observasi di lapangan selama satu tahun (2013) secara manual diperoleh nilai $\mathrm{r}^{2}$ sebesar 0,76 dan NS sebesar 0,77. Sedangkan untuk proses validasi selama satu tahun (2014) diperoleh nilai $\mathrm{r}^{2}$ sebesar 0,86 dan NS sebesar 0,85. Untuk grafik model hasil validasi dan kalibrasi disajikan pada Gambar 4 dan Gambar 5.
Tabel 2. Analisis curah hujan dan debit model SWAT di DAS Ciliwung hulu dengan metode Moving Average dari tahun 2010 sampai dengan 2015

\begin{tabular}{llc}
\hline \multirow{4}{*}{ Hulu } & Rata-rata curah hujan & $\mathrm{r}$ \\
\cline { 2 - 3 } & Harian & 0,62 \\
& 3 Harian & 0,73 \\
& 5 Harian & 0,77 \\
& 7 Harian & 0,80 \\
10 Harian & 0,82 \\
\hline \multirow{4}{*}{ Tengah } & Rata-rata curah hujan & $\mathrm{r}$ \\
\cline { 2 - 3 } & Harian & 0,34 \\
& 3 Harian & 0,45 \\
& 5 Harian & 0,50 \\
& 7 Harian & 0,54 \\
& 10 Harian & 0,58 \\
\hline \multirow{6}{*}{ Hilir } & Rata-rata curah hujan & 0,20 \\
\cline { 2 - 3 } & Harian & 0,34 \\
& 3 Harian & 0,40 \\
& 5 Harian & 0,44 \\
& 7 Harian & 0,48 \\
\hline
\end{tabular}

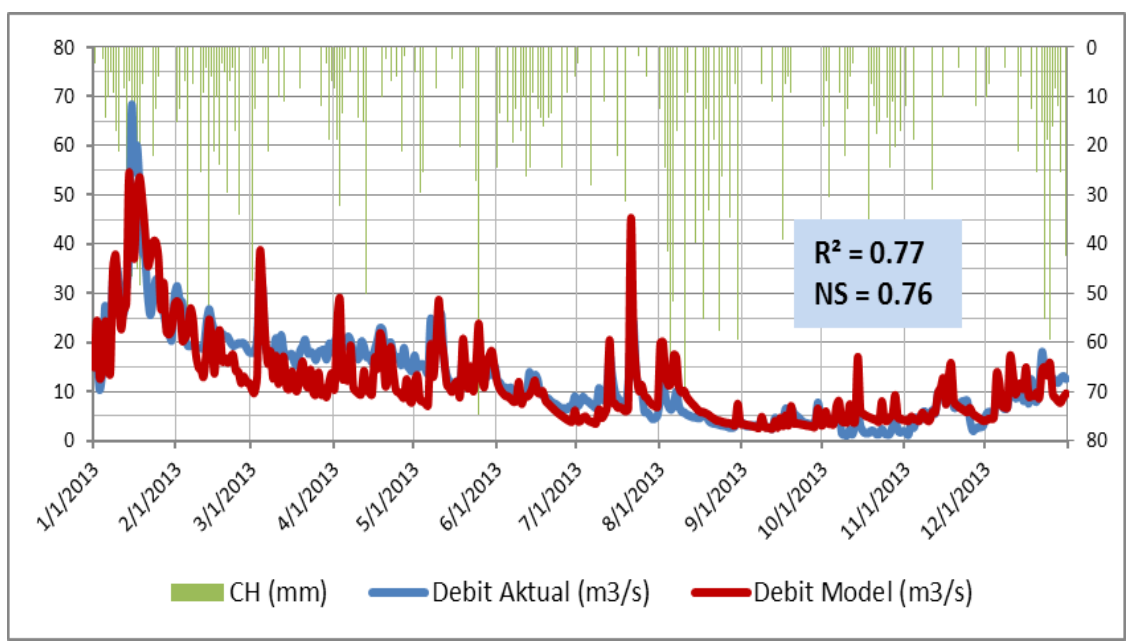

Gambar 4. Debit model hasil kalibrasi tahun 2013

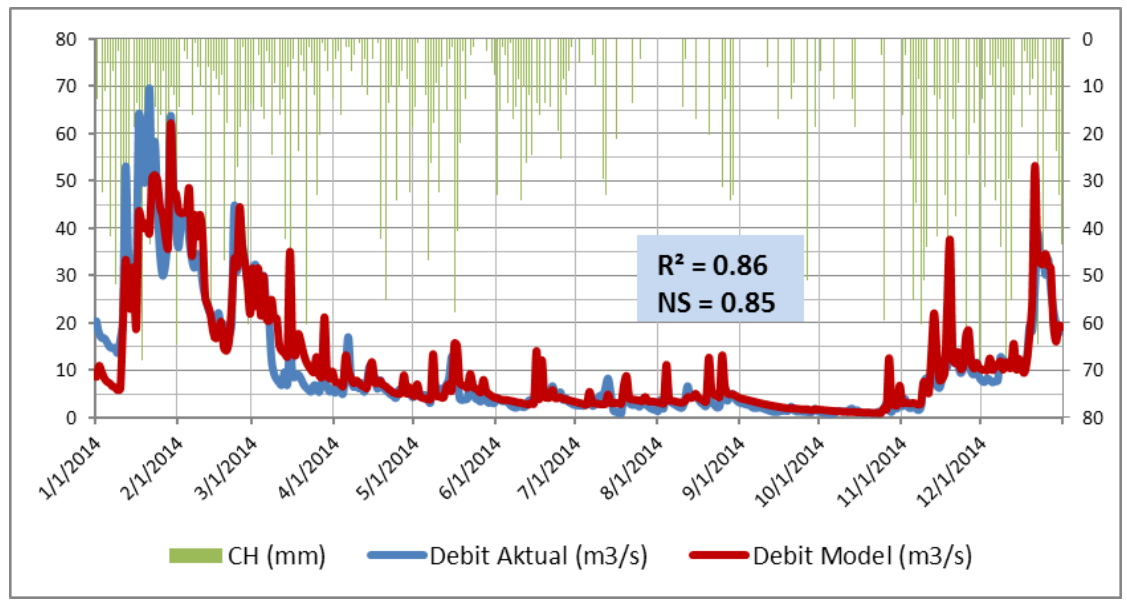

Gambar 5. Debit model hasil validasi tahun 2014 


\subsection{Analisis Debit Ratio rata-rata harian, 3 harian, 5 harian, 7 harian dan 10 harian) model SWAT}

Berdasarkan analisis data ratio batas atas dan bawah debit rata-rata harian, 3 harian, 5 harian, 7 harian dan 10 harian di hulu tengah dan hilir tahun 2010-2015 diperoleh data yang disajikan pada Tabel 3 dan Gambar 6 Batas atas ratio debit rata-rata menunjukkan nilai debit puncak, sedangkan batas bawah ratio debit ratarata menunjukkan nilai aliran dasar (baseflow).

Tabel 3. Ratio debit rata-rata DAS Ciliwung hulu tahun 2010-2015

\begin{tabular}{cllrl}
\hline Ratio Debit Rata-rata & Hulu & Tengah & Hilir \\
\hline \multirow{2}{*}{ Harian } & atas & 4,498 & 3,754 & 3,336 \\
& bawah & 0,104 & 0,110 & 0,129 \\
\hline \multirow{2}{*}{3 harian } & atas & 3,659 & 3,245 & 2,876 \\
& bawah & 0,098 & 0,109 & 0,122 \\
\hline \multirow{2}{*}{ 5 harian } & atas & 3,437 & 3,071 & 2,690 \\
& bawah & 0,097 & 0,110 & 0,124 \\
\hline \multirow{2}{*}{7 harian } & atas & 3,268 & 2,915 & 2,636 \\
& bawah & 0,096 & 0,111 & 0,124 \\
\hline \multirow{2}{*}{ 10 harian } & atas & 3,020 & 2,811 & 2,517 \\
& bawah & 0,094 & 0,109 & 0,124 \\
\hline
\end{tabular}

Berdasarkan data pada Tabel 3 dan Gambar 6 dapat diketahui bahwa ratio batas atas debit cenderung menurun dari hulu ke hilir, sedangkan ratio batas bawah debit cenderungan meningkat dari hulu ke hilir. Hal ini menunjukkan bahwa di DAS Ciliwung Hulu debit puncak dari hulu ke hilir cenderung menurun dan aliran dasar (baseflow) dari hulu ke hilir cenderung meningkat. Hal ini disebabkan ketika air mengalir dari hulu ke hilir, terdapat bagian yang hilang karena evaporasi dan menyebar melalui badan saluran. Kehilangan lainnya yang potensial yaitu pergerakan air dari saluran ke area pertanian atau penggunaan oleh manusia. Aliran dapat digantikan oleh hujan yang jatuh langsung ke dalam saluran dan tambahan air dari debit sungai. Sehingga debit puncak cenderung semakin menurun dari hulu ke hilir dan aliran dasar (baseflow) cenderung semakin meningkat dari hulu ke hilir. Berdasarkan data pada Tabel 3 di DAS Ciliwung Hulu di daerah hulu memiliki ratio debit puncak dan aliran dasar paling tinggi sehingga lebih diperlukan tindakan konservasi tanah dan air maupun sipil teknis.

Aliran dasar (baseflow) merupakan air tanah yang berkontribusi untuk debit sungai pada musim kemarau (Arnold et al., 2012). Aliran dasar (baseflow) dari hulu ke hilir cenderung meningkat, menunjukkan bahwa cadangan air pada musim kemarau dari hulu ke hilir memiliki kecenderungan meningkat.

Batas atas ratio debit rata-rata menunjukkan nilai dari debit puncak, sedangkan batas bawah ratio debit rata-rata menunjukkan nilai dari aliran dasar (baseflow). Data tersebut menunjukkan bahwa ratio batas atas debit memiliki trend menurun dari hulu ke hilir, sedangkan ratio batas bawah debit memiliki trend meningkat dari hulu ke hilir. Hal ini menunjukkan bahwa di DAS Ciliwung hulu debit puncak dari hulu ke hilir memiliki trend semakin menurun dan aliran dasar (baseflow) dari hulu ke hilir memiliki trend semakin meningkat. Hal ini terkait dengan curah hujan yang jatuh di DAS Ciliwung Hulu dari hulu ke hilir semakin rendah sehingga debit puncak dari hulu ke hilir semakin menurun baik di ratio debit rata-rata harian, 3 harian, 5 harian, 7 harian dan 10 harian. Hal ini menunjukkan bahwa di DAS Ciliwung Hulu di daerah hulu memiliki ratio debit puncak dan aliran dasar paling tinggi sehingga perlu dilakukan tindakan konservasi tanah dan air maupun sipil teknis.

Aliran dasar (baseflow) dari hulu ke hilir memiliki trend meningkat, disebabkan oleh akumulasi dari aliran dasar yang mengalir dari hulu ke hilir. Ratio batas atas debit rata-rata harian, 3 harian, 5 harian, 7 harian, dan 10 harian memiliki trend menurun dari hulu ke hilir. Ratio batas debit rata-rata harian, 3 harian, 5 harian, 7 harian, dan 10 harian memiliki trend meningkat dari hulu ke hilir. Pada debit harian memiliki nilai ratio debit rata-rata batas atas dan batas bawah paling tinggi bila dibandingkan dengan nilai debit rata-rata 3 harian, 5 harian, 7 harian dan 10 harian. Hal ini terkait range data debit harian lebih lebar bila dibandingkan dengan debit 3 harian, 5 harian, 7 harian dan 10 harian. Semakin lebar range data maka nilai ratio batas atas dan batas bawah akan semakin besar

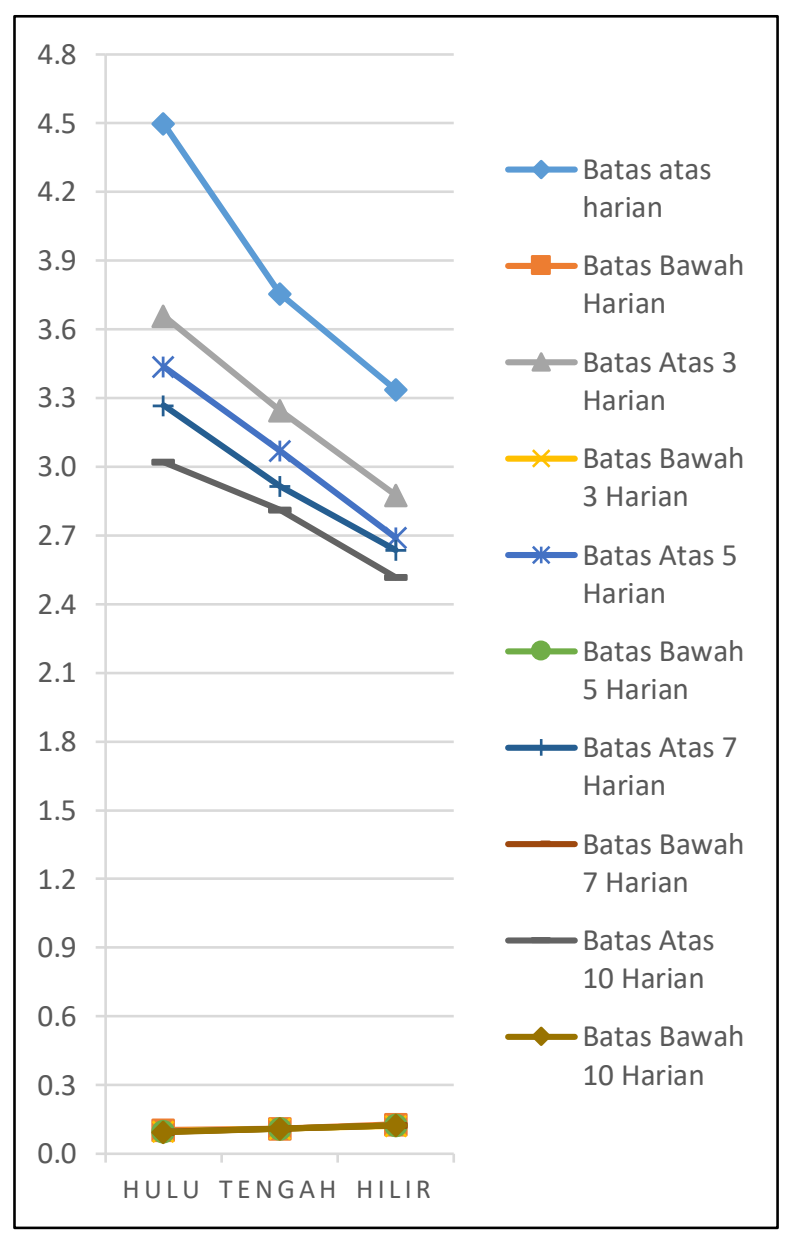

Gambar 6. Ratio debit rata-rata harian, 3 harian, 5 harian, 7 harian dan 10 harian DAS Ciliwung Hulu tahun 20102015. 


\section{Kesimpulan}

Dari hasil pembahasan di atas dapat disimpulkan bahwa

1. Model SWAT dapat diaplikasikan dengan baik di DAS Ciliwung hulu

2. Curah hujan rata-rata yang paling bepengaruh terhadap karakteristik hidrologi adalah curah hujan rata-rata 10 harian. Pada curah hujan rata-rata 10 harian semua komponen aliran telah berkontribusi maksimal untuk debit sungai

\section{Daftar Pustaka}

[1] Arnold, J. G., Kiniry, J. R., Srinivasan, R., Williams, J. R., Haney, E. B., Neitsch, S. L., 2012. Input/Output Documentation Version 2012. Texas (US), Texas Water Resources Institute.

[2] Arnold, J. G., Gassman, P. W., White, M. J., 2010. New developments in the SWAT ecohydrology model. In Proc. 21st Watershed Technology Conf.: Improving Water Quality and Environment. ASABE Publication No. 701P0210cd. St Joseph (US), ASABE.

[3] Asdak, C., 2007. Hidrologi dan Pengelolaan Daerah Aliran Sungai. Yogyakarta (ID), UGM Pr.

[4] [BPPP] Badan Penelitian dan Pengembangan Pertanian, 2013 Adaptasi Terhadap Variabilitas dan Perubahan Iklim Melalui Sistem Informasi Kalender Tanam Terpadu. [terhubung berkala]. http://www.deptan.go.id [22 Agustus 2016].

[5] Mukid, M. A., Wilandari, Y., 2012. Identifikasi Pola Distribusi Curah Hujan Maksimum dan Pendugaan Parameternya Menggunakan Metode Bayesian Markov Chain Monte Carlo. Media Statistika 5 (2), pp. 63-74.

[6] Nash, J. E., J. V. Sutcliffe, 1970. River Flow Forecasting Through Conceptual Models Part I Discussion of Principles. Journal of Hydrology 10 (3), pp. 282-190.

[7] Riajaya, P.D. 2006. Sebaran Curah Hujan Sebagai Dasar Penetapan Waktu Tanam Kapas pada Lahan Sawah Sesudah Padi di Lamongan Jawa Timur. J Perspektif 5 (1), pp. 26-35.

[8] Sudiharto. 2004. Kelayakan Penerapan Metode Oldeman untuk Klasifikasi Tipe Hujan di Perkebunan Karet. J Penelitian Karet 22 (2), pp. 23-35. 